Article

\title{
Anti-Breast Cancer Activity of Latroeggtoxin-V Mined from the Transcriptome of Spider Latrodectus tredecimguttatus Eggs
}

\author{
Dehong $X u^{1,2}$, Xiaochao Tang ${ }^{1}$, Xinzhou Wu ${ }^{1}$, Dianmei Yu ${ }^{1}$, Pingping Tang ${ }^{1}$ and \\ Xianchun Wang ${ }^{1, *}$ \\ 1 Key Laboratory of Protein Chemistry and Developmental Biology of Ministry of Education, \\ College of Life Sciences, Hunan Normal University, Changsha 410081, China; xudehong163@126.com (D.X.); \\ flower92931@outlook.com (X.T.); wuxinzhouwu@163.com (X.W.); yudianmei@outlook.com (D.Y.); \\ Pingpingtang@smail.hunnu.edu.cn (P.T.) \\ 2 Laboratory of Biological Engineering, College of Pharmacy, Hunan University of Chinese Medicine, \\ Changsha 410208, China \\ * Correspondence: wangxc@hunnu.edu.cn; Tel.: +86-731-8887-2556
}

Received: 10 October 2018; Accepted: 31 October 2018; Published: 2 November 2018

check for updates

\begin{abstract}
As a black widow spider, Latrodectus tredecimguttatus has poisonous components not only in venomous glands but also in eggs. Our previous work had carried out a transcriptome analysis of the spider eggs in an attempt to probe into the molecular basis of the egg toxicity. A proteinaceous toxin, named Latroeggtoxin- $\mathrm{V}$, was mined from the identified transcriptome. In this study, the gene of Latroeggtoxin- $\mathrm{V}$ was cloned and heterologously expressed, and the anticancer activity of the recombinant Latroeggtoxin- $\mathrm{V}$ (rLatroeggtoxin- $\mathrm{V}$ ) was characterized. Activity assay found that rLatroeggtoxin- $V$ could selectively act on breast cancer line MDA-MB-231 cells, not only arresting their cell cycle, inhibiting their proliferation and migration, but also inducing their apoptosis. Bioinformatics analysis suggested that Latroeggtoxin- $\mathrm{V}$ belongs to the ATPase inhibitor protein family and the further activity assay showed that the rLatroeggtoxin- $\mathrm{V}$ inhibited the activity of the $\mathrm{Na}^{+} / \mathrm{K}^{+}$-ATPase in MDA-MB-231 cells in a concentration-dependent manner, suggesting that the anticancer activity of Latroeggtoxin- $\mathrm{V}$ is based on its affecting the ion transport and receptor functions of $\mathrm{Na}^{+} / \mathrm{K}^{+}$-ATPase. The present work not only laid the foundation for the utilization of Latroeggtoxin- $\mathrm{V}$ in the anticancer drug development and the related fields, but also provided a new paradigm for exploration of the proteinaceous toxins under the direction of transcriptomics and bioinformatics.
\end{abstract}

Keywords: Latroeggtoxin-V; Recombinant expression; MDA-MB-231; anticancer activity; ATPase inhibitor; Latrodectus tredecimguttatus egg

Key Contribution: (i) Demonstrating that Latroeggtoxin-V has anti-breast cancer activity and shows a promising application foreground in the development of anti-breast cancer drugs; (ii) Providing a transcriptomics and bioinformatics-directed paradigm for exploring the proteinaceous toxins difficult to isolate from natural materials directly.

\section{Introduction}

Spider Latrodectus tredecimguttatus, also known as the "black widow", belongs to Arthropoda, Arachnoidea, Araneida, Theridiidae, Latrodectus in zoology and is one of the most poisonous spiders known in the world [1,2]. L. tredecimguttatus can release highly toxic venom, causing severe pain in the whole body after being stung by it and leading to functional or organic diseases of single 
or multiple organs such as liver, brain, kidney, heart and lung, and can even lead to death $[3,4]$. Furthermore, it had been found that not only does the venom of L. tredecimguttatus contain many toxic components [5-9], but that other parts of the body and even the eggs produced by it are also toxic [5,10-12]. In recent years, our research group has carried out a systematic study on the toxicity of the eggs using a combination of multiple techniques including proteomics and transcriptomics. The proteomic results showed that there are a variety of proteinaceous toxins in the eggs, which are significantly different from those in the venom, indicating that the eggs have the distinct molecular basis of toxicity [13]. By comprehensively using multiple techniques, four proteinaceous toxins, named Latroeggtoxin-I to Latroeggtoxin-IV, were purified and characterized from the eggs. Latroegtoxin-I is a neurotoxic protein and can block the neuromuscular transmission [14]. Latroeggtoxin-II selectively inhibits the TTX- $\mathrm{N} \mathrm{Na}^{+}$channel current in rat dorsal root ganglion neurons, showing toxicity toward both mice and Periplaneta americana [15]. Latroeggtoxin-III is an insect-specific protein toxin, whereas Latroeggtoxin-IV an antibacterial peptide [16]. No doubt, these proteinaceous toxins play important roles in the egg toxicity. However, there must be other active components that participate in the egg toxicity. Nevertheless, some of them, due to their too low abundance, are difficult to purify from the eggs, which limits us to understanding the molecular basis of the egg toxicity and utilizing the active components in the eggs.

At present, various omics strategies have successively emerged in the field of life science, of which transcriptomics based on the second generation high-throughput sequencing has been widely used in gene expression analysis. With this technique, the researchers can comprehensively and rapidly obtain the genomic transcription information of the researched object, which is helpful for revealing the molecular basis and mechanism underlying different biological characteristics [17,18]. Our group has carried out a transcriptomic analysis of L. tredecimguttatus eggs, from which 280 open reading frames encoding possible proteinaceous toxins were identified and the biological functions of the encoded toxins were bioinformatically predicted [19], thus providing guidance for the subsequent gene cloning and activity screening. One open reading frames has attracted our attention because the protein it encodes has high homology with the reported anticancer peptide SK84 [20], suggesting that the egg protein might also have anticancer activity. Our present study cloned and heterologously expressed the gene of the egg protein, and experimentally demonstrated that this protein, named Latroeggtoxin- $\mathrm{V}$, is an ATPase inhibitor and has anticancer properties toward breast cancer line MDA-MB-231 cells, exhibiting potential application in the development of anticancer drugs.

\section{Results}

\subsection{Bioinformatic Analysis on Latroeggtoxin-V}

Bioinformatic analysis on Latroeggtoxin- $\mathrm{V}$ showed that the theoretical molecular weight (MW) and isoelectric point (pI) of this protein were $10.17 \mathrm{kDa}$ and 6.21 , respectively. The prediction of secondary structure indicated that two kinds of secondary structure units were contained in the Latroeggtoxin- $\mathrm{V}$ molecule: $\alpha$-helix and coil. The secondary structure was dominated by $\alpha$-helix formed by C-terminal sequence, accounting for $68.1 \%$ of the total sequence, while the remaining $21.9 \%$ was in the coil conformation (Figure 1A). The search of conserved domain found that Latroeggtoxin- $V$ has ATPase inhibitor domain and its sequence was homologous with mitochondrial ATPase inhibitors from several different organisms (Figure 1A,B), so it was speculated that Latroeggtoxin-V belongs to the mitochondrial ATPase inhibitor family. Of the homologous ATPase inhihtors, Sk84 and PSK (a peptide with terminal $\mathrm{S}$ and $\mathrm{K}$ residues) were reported to have anticancer and antibacterial activities [20,21], suggesting that Latroeggtoxin- $V$ may have such bioactivities. Besides, by analyzing the hydrophobicity of $\alpha$-helix in Latroeggtoxin- $V$, it was found that the $\alpha$-helix at the $C$-terminus of Latroeggtoxin- $V$ was amphipathic, with more hydrophobic amino acid residues, such as L, I, and F, being distributed on one side and more hydrophillic amino acid residues, such as K, E, D, and R, on the other (Figure 1C). In addition, COIL Server analysis showed that the $\alpha$-helix in C-terminal sequence of Latroeggtoxin- $V$ 
could form $\alpha$-helical coiled-coil conformation (Figure 1D), suggesting that Latroeggtoxin-V was likely to dimerize with itself through this structure [22].
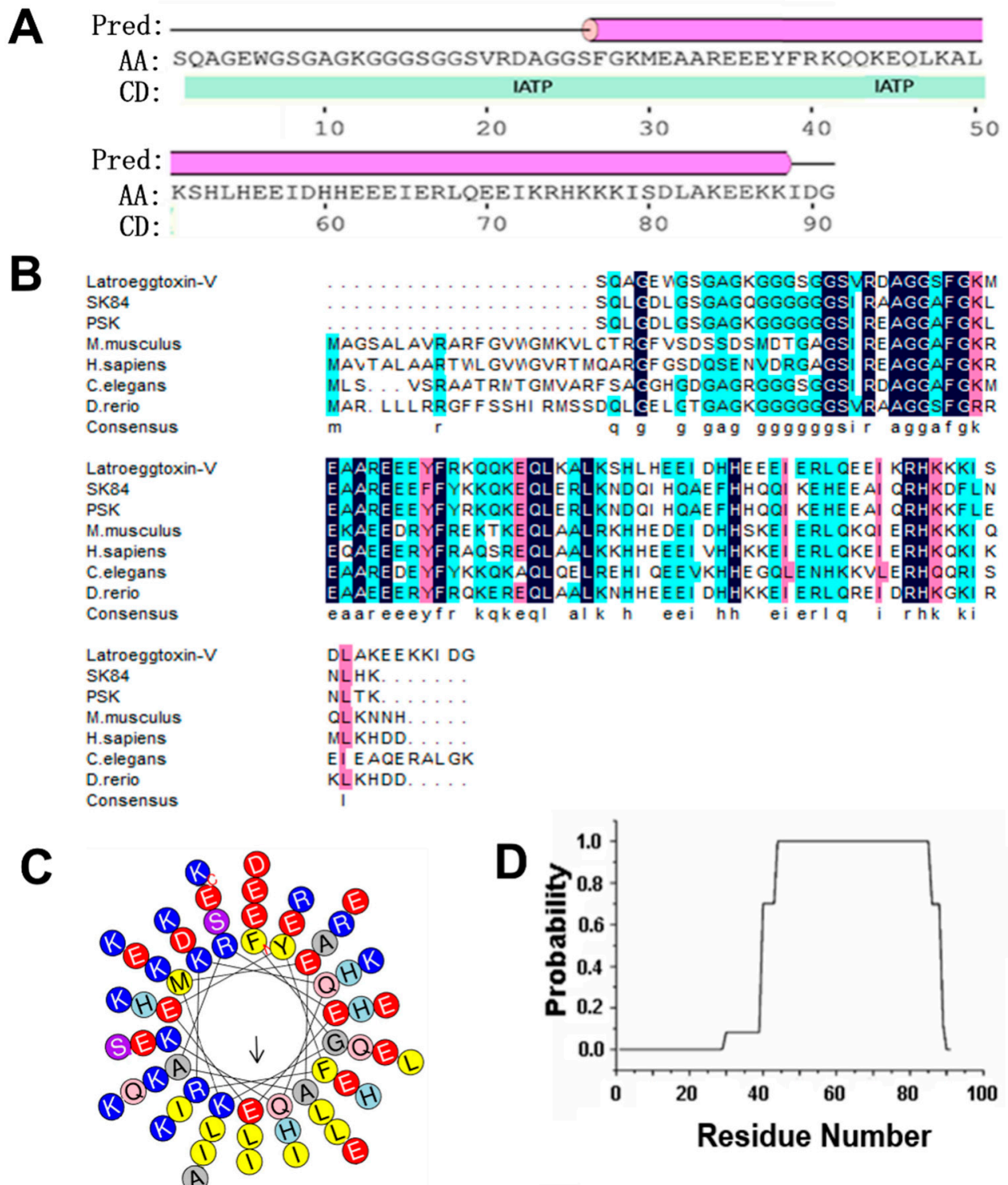

Figure 1. Bioinformatics analysis of Latroeggtoxin-V. (A) The conserved domain and secondary structures of Latroeggtoxin- $\mathrm{V}$. The 'pred' represents predicted secondary structure, of which the line represents coil, and the cylinder represents $\alpha$-helix. 'AA', 'CD' and 'IATP' indicate query sequence (Latroeggtoxin-V), conserved domain and ATPase inhibitor domain, respectively. (B) Homologous sequence alignment of Latroeggtoxin-V. Latroeggtoxin-V was aligned with mitochondrial ATPase inhibitory peptides from Drosophila melanogaster (SK84 and PSK), Mus musculus (NP_031538.2), Homo sapiens (NP_057395.1), Caenorhabditis elegans (NP_500336.1) and Danio rerio (NP_001082990.1). The identical residues are shaded in deep blue. The solid line at the bottom indicates the fragment corresponding to the minimal inhibitory sequence in ATPase inhibitor of bovine. (C) The helical wheel plots of $\alpha$-helix in Latroeggtoxin-V. The $\alpha$-helix of Latroeggtoxin-V shows amphipathic structural features, of which the hydrophobic face is indicated by an arrow. (D) Prediction of $\alpha$-helical coiled-coil in Latroeggtoxin-V. The line represents the probability of forming $\alpha$-helical coiled-coil participated in by each residue in Latroeggtoxin- $\mathrm{V}$, where the $\mathrm{C}$ terminal residues from $\mathrm{K} 44$ to E85 have the maximal probability $(100 \%)$ to form $\alpha$-helical coiled-coil. 


\subsection{Gene Cloning of Latroeggtoxin- $V$}

The extracted total RNA had excellent integrity confirmed by agarose gel electrophoresis (Figure $2 \mathrm{~A})$ and was of high purity $\left(\mathrm{OD}_{260 \mathrm{~nm}} / \mathrm{OD}_{280 \mathrm{~nm}}=1.9\right)$, with a concentration of $900 \mu \mathrm{g} / \mathrm{mL}$. According to the results of previous transcriptomic analysis of the eggs of L. tredecimguttatus, the nucleic acid sequence encoding Latroeggtoxin- $V$ as well as amino acid sequence was obtained (Figure 2B). Based on the sequence, gene-specific primers (Latroeggtoxin- $V$-F and Latroeggtoxin- $V$ - $\mathrm{R}$ ) were designed and used for PCR reaction, using the cDNA prepared by reverse transcription from the extracted total RNA as the template. Agarose gel electrophoresis and sequencing analysis showed that the PCR product was a 310-bp gene fragment that was consistent with that predicted (Figure 2C), suggesting successful gene cloning.
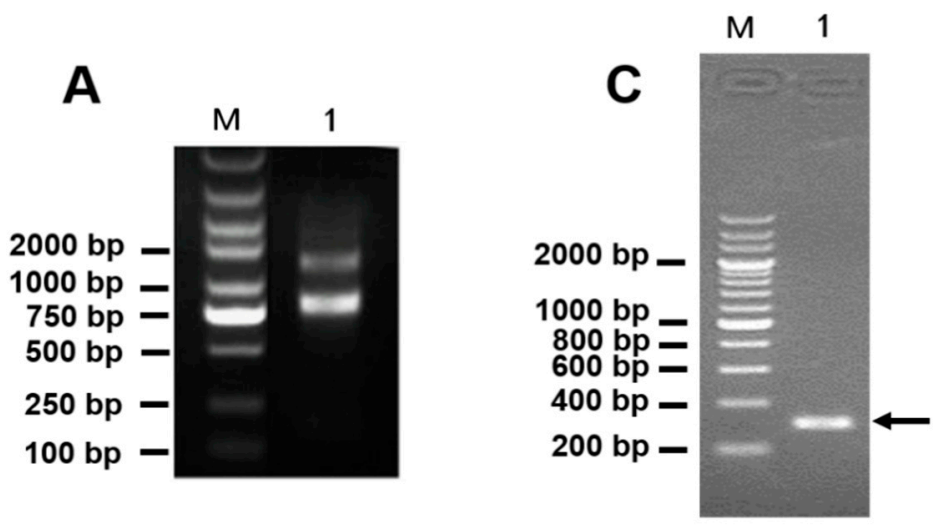

\section{B}

1 ATGTTTCGAATTGCGCGTCTTCGAGGAGCATCTGTAATGTTTTCATCATTCCGCTGTAAT

$\begin{array}{llllllllllllllllllllllll}1 & M & F & R & I & A & R & L & R & G & A & S & V & M & F & S & S & F & R & C & N\end{array}$

61 GGTTCTCAAGCAGGTGAATGGGGTAGCGGTGCTGGAAAGGGTGGAGGATCTGGTGGATCT

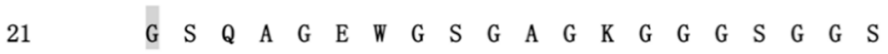

121 GTAAGAGATGCTGGTGGCAGTTTTGGTAAGATGGAGGCTGCACGAGAAGAAGAGTATTTT

$\begin{array}{lllllllllllllllllllll}41 & \text { V } & \text { R } & \text { D } & \text { A } & \text { G } & \text { G } & \text { S } & \text { F } & \text { G } & \text { K } & \text { M } & \text { E } & \text { A } & \text { A } & \text { R } & \text { E } & \text { E } & \text { E } & \text { Y } & \text { F }\end{array}$

181 AGAAAACAACAAAAGGAACAACTTAAAGCATTGAAAAGCCATTTGCATGAAGAAATTGAT

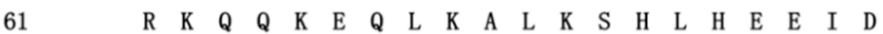

241 CACCATGAAGAAGAGATTGAGAGGTTGCAGGAAGAAATTAAGAGGCATAAGAAAAGATT

$\begin{array}{llllllllllllllllllllll}81 & H & H & E & E & E & I & E & R & L & Q & E & E & I & K & R & H & K & K & K & I\end{array}$

301 TCTGACTTAGCTAAAGAAGAGAAGAAAATTGATGGATGA

101

$\begin{array}{llllllllllllllllllll}S & D & L & A & K & E & E & K & K & I & D & G & *\end{array}$

Figure 2. Gene cloning of Latroeggtoxin-V. (A) Identification of the total RNA integrity with agarose gel electrophoresis. M, DNA marker; Lane 1, total RNA. (B) Nucleic acid sequence encoding Latroeggtoxin- $\mathrm{V}$ and the corresponding amino acid sequence. The signal sequence is shaded in gray, followed by the mature peptide sequence of Latingtoxin- $\mathrm{V}$. The asterisk indicates the stop codon. (C) Detection of PCR product of Latroeggtoxin-V gene with agarose gel electrophoresis. M, DNA marker; Lane 1, PCR product, a 310-bp nucleic acid sequence containing the 276-bp gene fragment and restriction endonuclease and enterokinase cleavage site sequences.

\subsection{Prokaryotic Expression and Purification of Latroeggtoxin-V Fusion Protein}

The gene fragment encoding the Latroeggtoxin- $\mathrm{V}$ mature peptide was successfully inserted between BamHI and XhoI sites in the pET-28a expression vector (Figure 3A), confirmed by double enzyme digestion (Figure 3B). After the recombinant vector was transformed into BL21 (DE3) E. coli, 
the protein expression was induced with IPTG, and SDS-PAGE showed that Latroeggtoxin- $V$ gene was efficiently expressed in the form of fusion protein with a molecular weight of about $14.30 \mathrm{kDa}$ consistent with that predicted (Figure 3C). After the E. coli cells were collected, lysed by sonication and centrifuged, the fusion protein in the supernatant was purified in a batchwise manner by Ni-NTA affinity chromatography under native conditions. The target fusion protein was eluted with $250 \mathrm{mM}$ imidazole, and SDS-PAGE demonstrated that the fusion protein had been efficiently purified (Figure 3C).
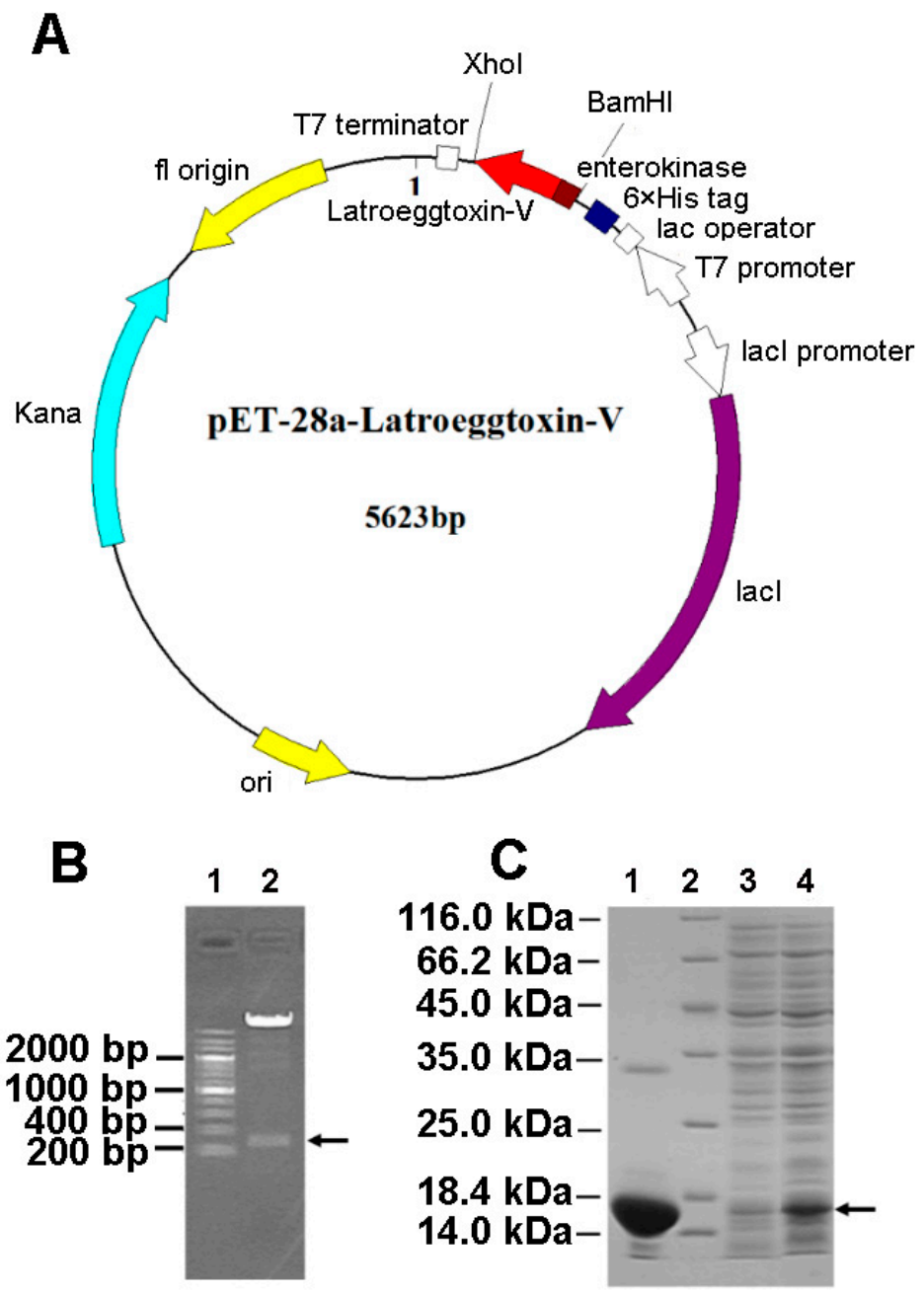

Figure 3. Gene cloning and fusion expression of Latroeggtoxin-V. (A) Plasmid map of Latroeggtoxin-V expression vector. The Latroeggtoxin- $V$ gene fragment was cloned into the expression vector pET-28a and expressed in the form of fusion protein containing a His tag and enterokinase cleavage sites. (B) Identification of recombinant plasmid pET-28a-Latroeggtoxin- $V$ by double enzyme digestion. Line 1, DNA marker; Lane 2, products of double enzyme digestion by BamHI and Xhol. The arrow indicates the Latroeggtoxin- $V$ gene fragment. (C) SDS-PAGE image showing expression and purification of Latroeggtoxin-V fusion protein. Line 2, protein marker; Lanes 1, 3 and 4, Latroeggtoxin-V fusion protein after purification, cell lysate before inducing by IPTG, and cell lysate after inducing by IPTG for $5 \mathrm{~h}$, respectively. The arrow indicates the expressed fusion protein.

\subsection{Acquisition and Identification of rLatroeggtoxin- $V$}

Since the Latroeggtoxin- $\mathrm{V}$ fusion protein contains an enterokinase cleavage site, the fusion protein tag can be removed with enterokinase. The products resulted from the enzymatic cleavage were separated by RP-HPLC (Figure 4A). From the figure, two main peaks were observed, and the 
molecular weight of the protein in the second peak at about 29.8 min was $10.1722 \mathrm{kDa}$ identified by electrospray mass spectrometry (Figure 4B), which was consistent with the theoretical molecular weight of Latroeggtoxin- $\mathrm{V}$, so that the peak was determined to be the desired peak. In addition, the mass spectrum shows a group of regular multiple-charge peaks, indicating that the rLatroeggtoxin- $V$ sample had been purified.
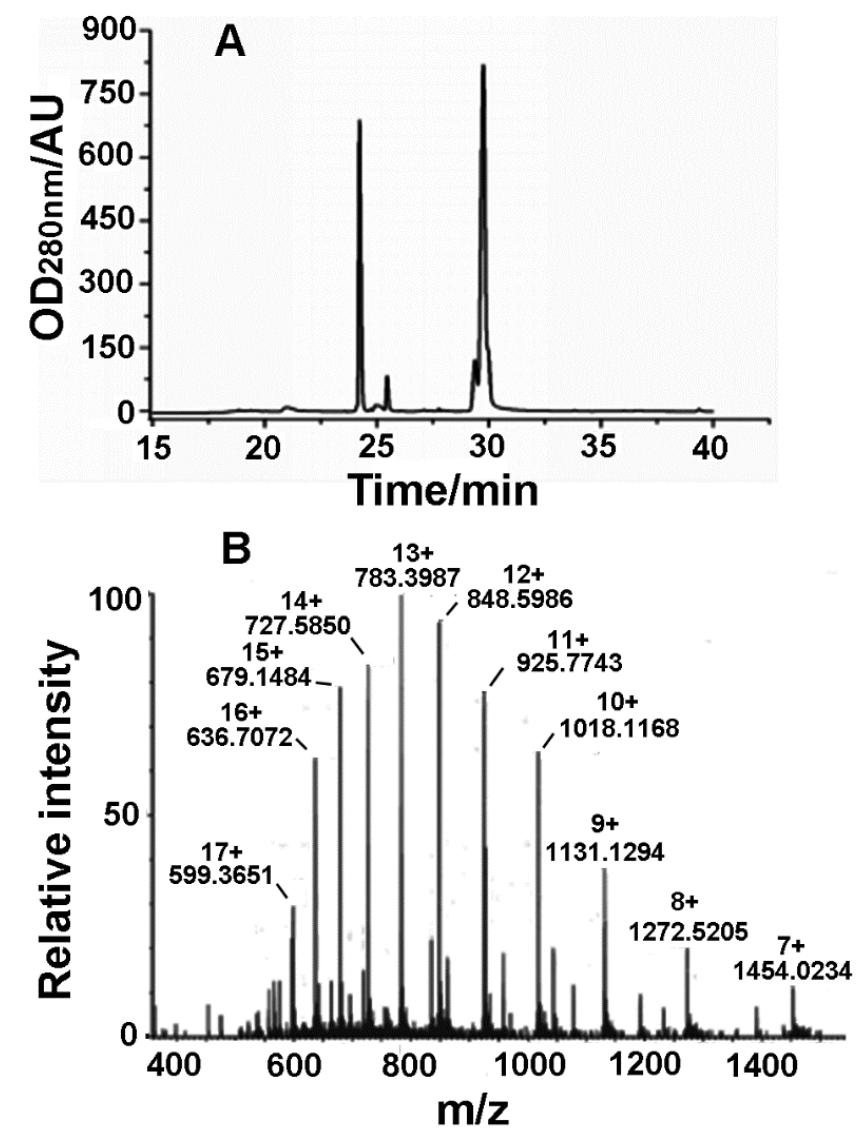

Figure 4. Purification and identification of rLatroeggtoxin-V. (A) Chromatogram of RP-HPLC purification of rLatroeggtoxin-V. (B) Molecular weight determination of rLatroeggtoxin-V by electrospray ionization mass spectrometry. The $m / z$ value and the number of charges for each rLatroeggtoxin- $V$ ion peak were labeled.

\subsection{Effects of rLatroeggtoxin-V on Cell Viability}

After the MDA-MB-231 and HEK293 cells were treated with different concentrations of rLatroeggtoxin- $\mathrm{V}(0,20,40,60$ and $80 \mu \mathrm{M})$ for $48 \mathrm{~h}$, the cell viability was assessed by MTT assay. The results (Figure 5) showed that rLatroeggtoxin-V decreased the cell viability both of the MDA-MB-231 and HEK293 cells in a concentration-dependent fashion, suggesting that rLatroeggtoxin-V inhibited the proliferation of the two kinds of cells. However, the inhibition of proliferation in MDA-MB-231 cells by rLatroeggtoxin- $V$ was much more significant than that in HEK293 cells $(p<0.05$ and 0.01$)$, indicating that the inhibitory effect of rLatroeggtoxin- $V$ on the proliferation in MDA-MB-231 breast cancer cells has selectivity. The $\mathrm{IC}_{50}$ of rLatroeggtoxin-V against MDA-MB-231 cells was calculated to be about $43 \mu \mathrm{M}$. 


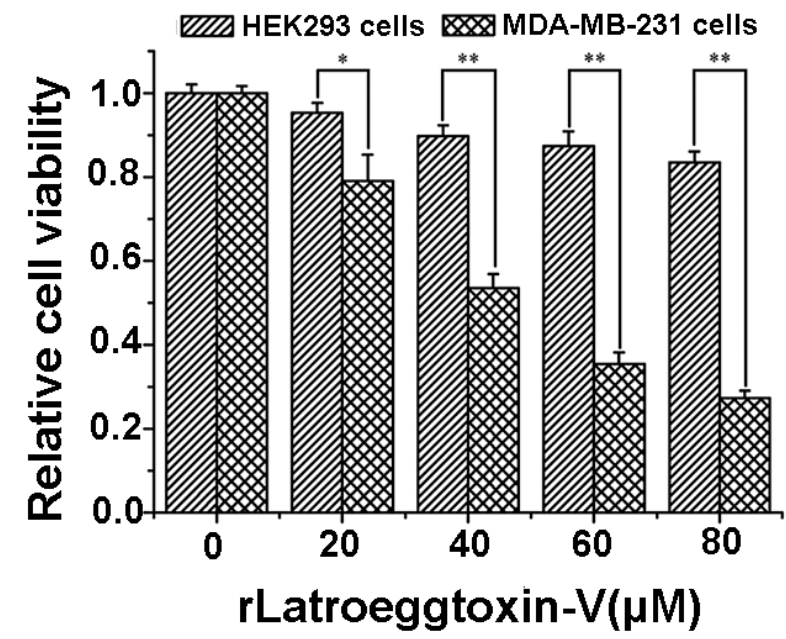

Figure 5. Comparison of the inhibitory effects of rLatroeggtoxin-V on the proliferation in HEK293 and MDA-MB-231 cells. ${ }^{*} p<0.05 ;{ }^{* *} p<0.01$. The data are represented as mean \pm SD. $(n=4)$.

\subsection{Apoptosis of MDA-MB-231 Cells Induced by rLatroeggtoxin-V}

In order to investigate whether rLatroeggtoxin- $\mathrm{V}$, besides inhibiting the proliferation in the MDA-MB-231 cells, can decrease the viability of MDA-MB-231 cells through inducing apoptosis, apoptotic morphology of the cells treated with $40 \mu \mathrm{M}$ rLatroeggtoxin- $\mathrm{V}$ and untreated cells was comparatively observed after Hoechst 33258 staining. The results showed that the karyopyknosis characteristic of apoptosis appeared in some cells treated with rLatroeggtoxin- $\mathrm{V}$ for $48 \mathrm{~h}$ (Figure 6A), but not in untreated cells (Figure 6B). This phenomenon demonstrated that the inhibitory effect of rLatroeggtoxin- $\mathrm{V}$ on the viability of MDA-MB-231 cells was partially due to its inducing apoptosis.
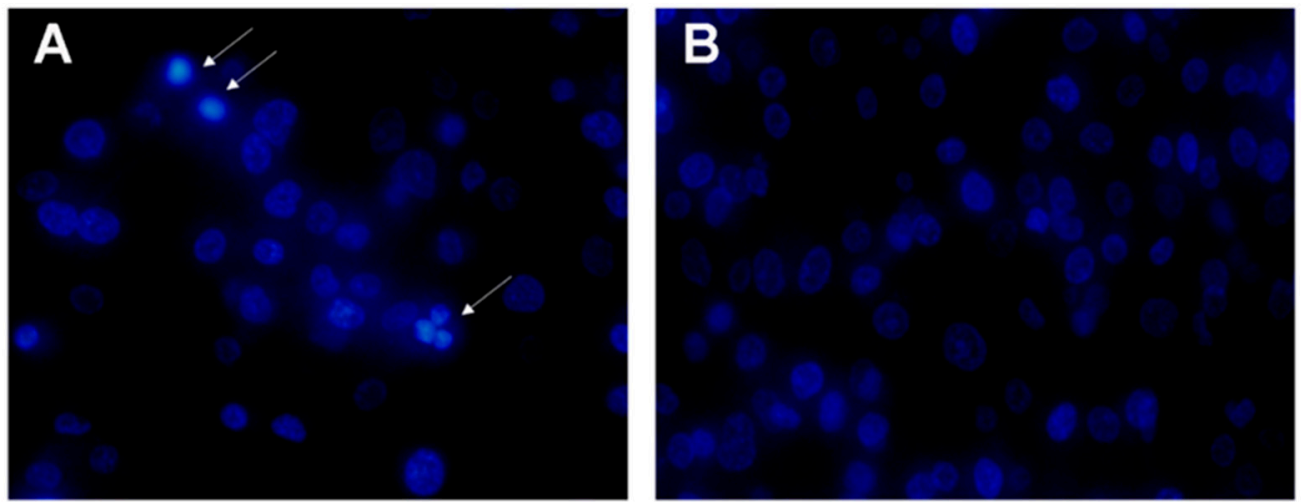

Figure 6. Hoechst 33258 staining for observing apoptosis of MDA-MB-231 cells induced by rLatroeggtoxin-V. (A) The fluorescence micrograph of $40 \mu \mathrm{M}$ rLatroeggtoxin-V treatment for $48 \mathrm{~h}$ $(400 \times)$. White arrows indicate apoptotic cells with pyknotic nucleus. (B) The fluorescence micrograph of untreated MDA-MB-231 cells $(400 \times)$.

\subsection{Inhibition of $M D A-M B-231$ Cell Migration by rLatroeggtoxin- $V$}

In view of the fact that MDA-MB-231 cells have strong invasiveness, the wound-healing assay was performed to detect the effect of rLatroeggtoxin- $\mathrm{V}$ on the migration ability of MDA-MB-231 cells in culture. The results demonstrated that the migration distance of MDA-MB-231 cells was continuously decreased as the concentration of the rLatroeggtoxin- $\mathrm{V}$ was increased. Compared with the control, the differences reached extremely significant level $(p<0.01)$ (Figure 7). This result demonstrated that rLatroeggtoxin- $\mathrm{V}$ could weaken the migration ability of MDA-MB-231 cells in a concentration-dependent manner. 
A
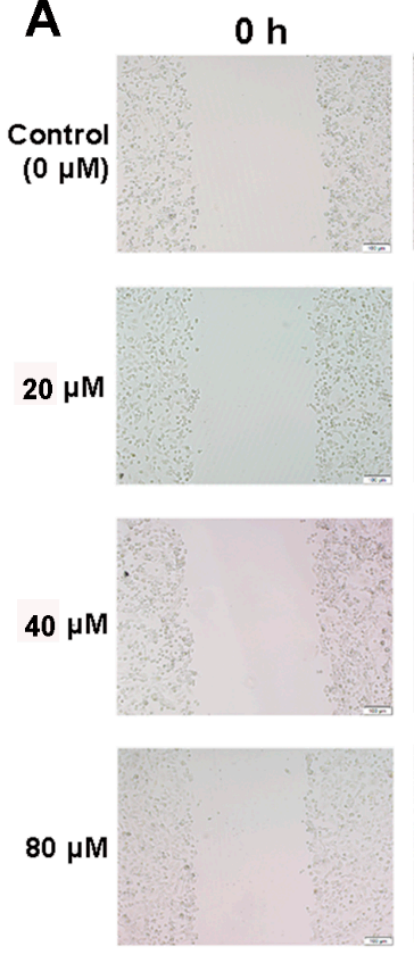

B

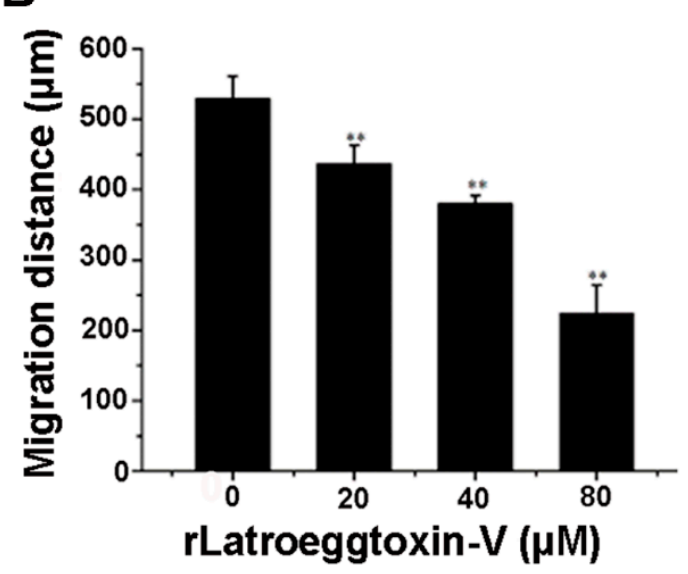

Figure 7. Wound-healing assay for detecting the effect of rLatroeggtoxin-V on MDA-MB-231 cell migration. (A) Wound-healing of MDA-MB-231 cells with or without treatment with rLatroeggtoxin-V at different concentrations for $24 \mathrm{~h}$. (B) Comparison of MDA-MB-231 cell migration distances after treatment with rLatroeggtoxin-V at different concentrations for 24 h. ${ }^{* *} p<0.01$ when compared with the control. The data are represented as mean \pm SD. $(n=3)$.

\subsection{MDA-MB-231 Cell Cycle Arrest Caused by rLatroeggtoxin-V}

As shown in Figure 8 and Table 1, rLatroeggtoxin-V could affect the cell cycle distribution of MDA-MB-231. The percentage of MDA-MB-231 cells in $\mathrm{G}_{0} / \mathrm{G}_{1}$ phase increased with the increase of rLatroeggtoxin- $\mathrm{V}$ concentration. When the concentrations of rLatroeggtoxin- $\mathrm{V}$ were $50 \mu \mathrm{M}$ and above, the percentage of MDA-MB-231 cells in $\mathrm{G}_{0} / \mathrm{G}_{1}$ phase was significantly higher than that of the control $(p<0.05)$. Correspondingly, the percentage of the MDA-MB-231 cells in S phase was significantly lowed, and that of the MDA-MB-231 cells in $\mathrm{G}_{2} / \mathrm{M}$ phase was not significantly changed. These results indicate that rLatroeggtoxin- $V$ could induce cell cycle arrest at $G_{0} / G_{1}$ phase in the MDA-MB-231 cells. 

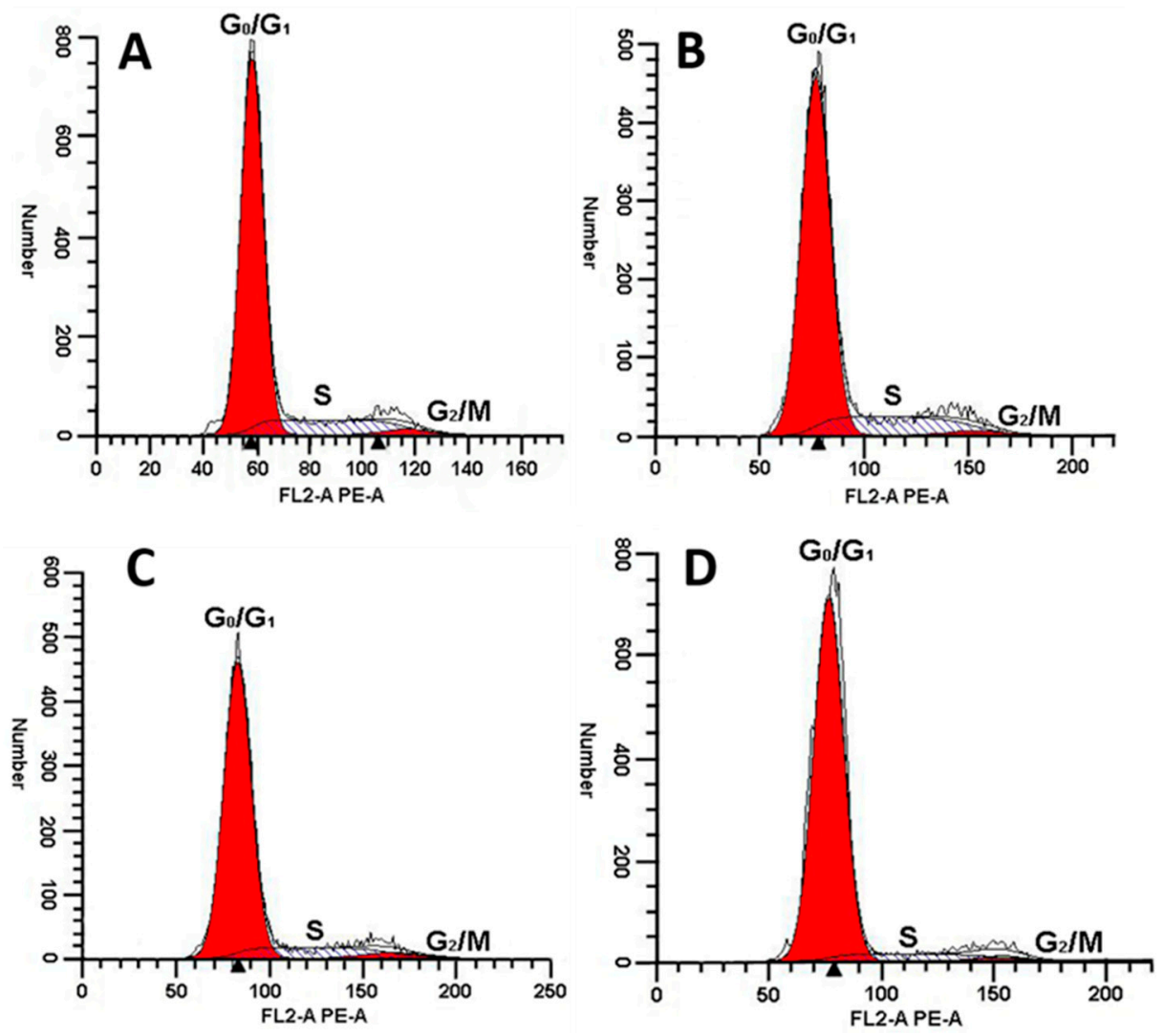

Figure 8. Effect of rLatroeggtoxin-V at different concentrations on MDA-MB-231 cell cycle. Exposure of MDA-MB-231 cells to (A, Control) $0 \mu \mathrm{M}$, (B) $25 \mu \mathrm{M}$, (C) $50 \mu \mathrm{M}$ and (D) $100 \mu \mathrm{M}$ rLatroeggtoxin- $\mathrm{V}$ for $48 \mathrm{~h}$ increased the cell population in the $\mathrm{G}_{0} / \mathrm{G}_{1}$ phases, and decreased that in the $S$ phase.

Table 1. Cell cycle distribution of MDA-MB-231cells treated with rLatroeggtoxin-V.

\begin{tabular}{cccc}
\hline \multirow{2}{*}{ Treatment } & \multicolumn{3}{c}{ Cell Cycle Distribution (\%) } \\
\cline { 2 - 4 } & $\mathbf{G}_{\mathbf{0}} / \mathbf{G}_{\mathbf{1}}$ & $\mathbf{S}$ & $\mathbf{G}_{\mathbf{2}} / \mathbf{M}$ \\
\hline Control $(0 \mu \mathrm{M})$ & $80.80 \pm 0.69$ & $16.22 \pm 1.22$ & $2.98 \pm 0.7$ \\
$25 \mu \mathrm{M}$ & $81.59 \pm 1.65$ & $15.81 \pm 1.91$ & $2.98 \pm 0.7$ \\
$50 \mu \mathrm{M}$ & $83.25 \pm 0.73^{\mathrm{a}}$ & $13.83 \pm 0.77^{\mathrm{a}}$ & $2.91 \pm 0.15$ \\
$100 \mu \mathrm{M}$ & $89.67 \pm 1.39^{\mathrm{a}}$ & $8.33 \pm 0.38^{\mathrm{a}}$ & $2.00 \pm 1.09$ \\
\hline
\end{tabular}

${ }^{a}$ significantly different compared with the control $(p<0.05)$. Each group of data comes from the average of three measurements, expressed as mean $\pm \mathrm{SD}$. $(n=3)$.

\section{9. $r$ Latroeggtoxin-V Inhibition of $\mathrm{Na}^{+} / \mathrm{K}^{+}$-ATPase of $\mathrm{MDA}-\mathrm{MB}-231$ Cells}

After the MDA-MB-231 cells were treated with different concentrations of rLatroeggtoxin-V $(0,10$, 100 and $1000 \mu \mathrm{M}$ ) for 0 and $24 \mathrm{~h}$, the cells were separately harvested and their $\mathrm{Na}^{+} / \mathrm{K}^{+}$-ATPase activities were determined using a Na${ }^{+} / \mathrm{K}^{+}$-ATPase assay kit (Solarbio, Shanghai, China). The results showed that rLatroeggtoxin- $\mathrm{V}$ could in vitro inhibit the activity of $\mathrm{Na}^{+} / \mathrm{K}^{+}$-ATPase in a concentration-dependent manner (Figure 9). When rLatroeggtoxin- $\mathrm{V}$ concentration was $1 \mathrm{mM}$, the specific activity of the $\mathrm{Na}^{+} / \mathrm{K}^{+}$-ATPase was $5.03 \pm 0.48 \mathrm{U} / \mathrm{mg}$, significantly lower than that $(6.46 \pm 0.57 \mathrm{U} / \mathrm{mg})$ of control $(p<0.05)$. 


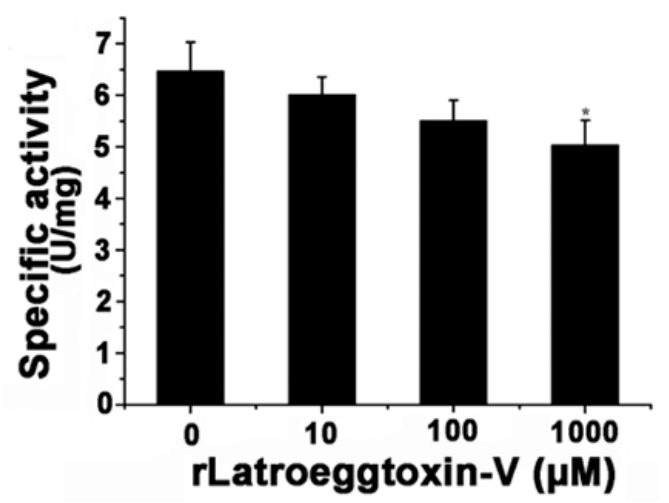

Figure 9. Effect of rLatroeggtoxin-V on the activity of $\mathrm{Na}^{+} / \mathrm{K}^{+}$-ATPase from MDA-MB-231 cells after treatment with different concentrations of rLatroeggtoxin-V. ${ }^{*} p<0.05$ when compared with the control. The data are represented as mean $\pm \mathrm{SD}$. $(n=3)$.

\section{Discussion}

The conventional strategy for obtaining and studying the desired proteinaceous toxins and other bioactive components is to directly extract them from natural materials followed by activity screening. This strategy has limitations such as high cost, low yield and long period, particularly when the natural material is limited, the material composition is complex, and the desired component is low-abundant. Next-generation sequencing-based transcriptomics provides an effective means to characterize the gene expression products. Theoretically, it is now possible to have virtually all the mRNAs in a sample to be identified and analyzed, which is suitable for rapidly obtaining the inventory of all proteinaceous components without the need for a reference genome. Transcriptome provides much information on the full-length as well as partial gene sequences encoding proteins and peptides, including those expressed in such a low abundance that it is impossible for them to be directly purified from the natural materials. The contemporary bioinformatics may predict the potential biofunctions of the expressed products, and thus narrow the range of activity screening. In our present study, we cloned and heterologously expressed a unigene selected from the L. tredecimguttatus egg transcriptome that encodes a protein: Latroeggtoxin- $\mathrm{V}$ that had not been isolated from the eggs due to its too low abundance and the complexity of the egg protein composition. BLAST analysis suggested that Latroeggtoxin- $\mathrm{V}$ might have activities of inhibiting $\mathrm{Na}^{+} / \mathrm{K}^{+}$-ATPase, anticancer and antibacterium (Figure 1). The experimental results demonstrated that rLatroeggtoxin- $V$, although showing no antibacterial activity against the tested bacteria Staphylococcus aureus and Bacillus subtilis (data not shown), could inhibit the $\mathrm{Na}^{+} / \mathrm{K}^{+}$-ATPase, proliferation and migration of breast cancer cell line MDA-MB-231 cells, and induce their apoptosis.

The $\mathrm{Na}^{+} / \mathrm{K}^{+}$-ATPase is a multiple-transmembrane plasma membrane protein complex that utilizes the energy from the hydrolysis of ATP to drive $3 \mathrm{Na}^{+}$out of cells and $2 \mathrm{~K}^{+}$into cells, which is essential for normal resting membrane potential and maintaining the electrolyte and fluid balance in cells, organs and whole body [23-25]. Inhibition of the $\mathrm{Na}^{+} / \mathrm{K}^{+}$-ATPase leads to depletion of intracellular $\mathrm{K}^{+}$and accumulation of intracellular $\mathrm{Na}^{+}$, which in turn results in membrane depolarization and increase in cytosolic free $\mathrm{Ca}^{2+}$ concentration due to activation of voltage-gated $\mathrm{Ca}^{2+}$ channels and reversed operation of the $\mathrm{Na}^{+} / \mathrm{Ca}^{2+}$ exchanger [25-27]. Calcium is a highly versatile intracellular signing and regulates many different cellular processes, such as gene transcription, cell growth, cell proliferation, cell differentiation, cell migration, mitochondrial redox state, etc. [28]. In addition, $\mathrm{Na}^{+} / \mathrm{K}^{+}$-ATPase also works as a cell surface receptor and a key player of cell adhesion, participating in modulation of cell signaling mechanism, affecting proliferation, cell-cell interaction, differentiation and apoptosis, etc. [29-31]. Generally speaking, $\mathrm{Na}^{+} / \mathrm{K}^{+}$-ATPase is a house-keeping enzyme with multiple specialized functions and is required for the normal physiological and biochemical activities even the survival of all cells [25]. The aberrant expression and activity of the $\mathrm{Na}^{+} / \mathrm{K}^{+}$-ATPase are related to the development and progression of breast cancer, 
the most prevalent malignancies found in women all over the world [31]. In view of the unique properties of the $\mathrm{Na}^{+} / \mathrm{K}^{+}$-ATPase, this enzyme could be used as a potentially important target for the development of anti-breast cancer drugs. Furthermore, the $\mathrm{Na}^{+} / \mathrm{K}^{+}$-ATPase can serve as a target for a number of ligands, thus providing even more possibilities for screening specific anti-breast cancer drugs [24,31-34]. For example, there have been reports indicating that cardiac glycosides are potent inhibitors of $\mathrm{Na}^{+} / \mathrm{K}^{+}$-ATPase and possess potent anti-breast cancer activity, displaying potential in the development of anti-breast cancer drugs [31]. Ouabain and digitoxin were demonstrated to be able to efficiently inhibit the migration of breast cancer MDA-MB-231 cells and their antimigratory effects are directly related to the inhibition of $\mathrm{Na}^{+} / \mathrm{K}^{+}$-ATPase-mediated $\mathrm{Na}^{+} / \mathrm{K}^{+}$transport [35]. Kometiani et al. reported that low concentrations of ouabain $(100 \mathrm{nM}$ or lower) caused only $<25 \%$ inhibition of pumping function of $\mathrm{Na}^{+} / \mathrm{K}^{+}$-ATPase in human breast cancer line MDA-MB-435s, and had no effect on cell viability, but inhibited proliferation by activating the $\mathrm{Na}^{+} / \mathrm{K}^{+}$-ATPase-mediated signaling pathways that led to the increase in the level of cell cycle inhibitor and the growth arrest [36]. However, due to the low (or lack of) specificity and other limitations (such as more easily to produce drug resistance) of the existing anti-cancer agents particularly those of small molecular weight, their clinical applications often have side effects and a relatively low success rate [37-40], which instigates the need for more effective and less side effect-causing drugs from natural resources.

The proteins and peptides with anticancer activity from the venomous animals constitute a new kind of library for anticancer drug screening. Compared with the small molecular drugs, proteinaceous ones have the advantages such as high selectivity and affinity for their molecular targets and difficultly making tumors develop resistance [41,42]. Until now, several proteinaceous components showing anticancer activities against breast cancer cells have been screened from the venomous animals. For example, melittin, the major peptide component in the venom of honey bee Apis mellifera, has been shown to suppress EGF-induced cell motility and invasion by inhibiting PI3K/Akt/mTOR signaling pathway in breast cancer cells [43]. Neopladine 1 and neopladine 2, two novel proteins with molecular weights of 29.918 and $30.388 \mathrm{kDa}$, respectively, were purified from the venom of scorpion Tityus discrepans and found to induce apoptosis of human breast carcinoma SKBR3 cells but has a negligible effect on non-malignant MA104 monkey kidney cells [44]. The proteinaceous toxin $\mathrm{C} 13 \mathrm{~S} 1 \mathrm{C} 1$ from the venom of Eastern green mamba, Dendroaspis angusticeps (Elapidae) shows strong cytotoxicity against breast adenocarcinoma MDA-MB-231 cells [45]. Latroeggtoxin-V investigated in our present study is a proteinaceous toxin mined from the spider L. tredecimguttatus egg transcriptomic data with the help of bioinformatics. The experimental results showed that the rLatroeggtoxin- $\mathrm{V}$ at the lower tested concentrations could induce apoptosis of breast cancer MDA-MB-231 cells (Figure 6), inhibit migration of the cancer cells, arrest the cell cycle and thus inhibit the proliferation in a concentration-dependent fashion (Figures 5, 7 and 8; Table 1). At the same time, rLatroeggtoxin-V was demonstrated to in vitro inhibit the activity of $\mathrm{Na}^{+} / \mathrm{K}^{+}$-ATPase in MDA-MB-231 cells in a concentration-dependent manner, with the inhibition reaching significant level $(p<0.05)$ at a concentration of $1 \mathrm{mM}$ (Figure 7). It is worthy of mentioning that rLatroeggtoxin- $V$ efficiently inhibit MDA-MB-231 cells proliferation, and, however, the same dose of rLatroeggtoxin- $V$ had much lesser toxic effect on non-tumor- derived HEK 293 cells. The selective action of Latroeggtoxin- $V$ on the breast cancer cells makes the active protein present a promising prospect for the development of related drugs. In addition, the selective action of Latroeggtoxin-V suggests that there are differences in the structures of Latroeggtoxin-V-binding sites in the $\mathrm{Na}^{+} / \mathrm{K}^{+}$-ATPase of cancer cells and normal cells. Obviously, further research of the structural differences would be helpful for elucidating the molecular basis underlying the selectivity of action of Latroeggtoxin-V.

In light of the fact that the $\mathrm{Na}^{+} / \mathrm{K}^{+}$-ATPase not only has an ion transport function, but also has a cell-surface receptor function $[29,30]$, it can be postulated that the Latroeggtoxin-V exerts its effects on the breast cancer cells via at least two ways: Affecting the $\mathrm{Na}^{+} / \mathrm{K}^{+}$-ATPase receptor-mediated signaling pathways and changing the ionic homeostasis by inhibiting the activity of $\mathrm{Na}^{+} / \mathrm{K}^{+}$-ATPase in the MDA-MB-231 cells. Furthermore, although these two action pathways interacted and overlapped 
with each other to a certain degree, in the lower concentrations the effects of Latroeggtoxin- $V$ on the cancer cells might be due mainly to activation or inhibition of the related signaling pathways, and in the higher concentrations mainly to the disruption of ionic homeostasis, including the depletion of intracellular $\mathrm{K}^{+}$, accumulation of $\mathrm{Na}^{+}$and thus the increase of free $\mathrm{Ca}^{2+}$ in cytosol $[25,27]$. Bioinformatic analysis suggested that the $\mathrm{C}$-terminal sequence of Latroeggtoxin- $\mathrm{V}$ forms an $\alpha$-helix with amphipathic structural features, and the residues from K44 to E85 in the C-terminal sequence have the maximal probability $(100 \%)$ to form $\alpha$-helical coiled-coil structure by dimerization, which is a prerequisite for the ATPase inhibitory action and biomedical application [46-48]. Taken together, the actions of Latroeggtoxin-V on breast cancer cell line MDA-MB-231 cells can be summarized in Figure 10.

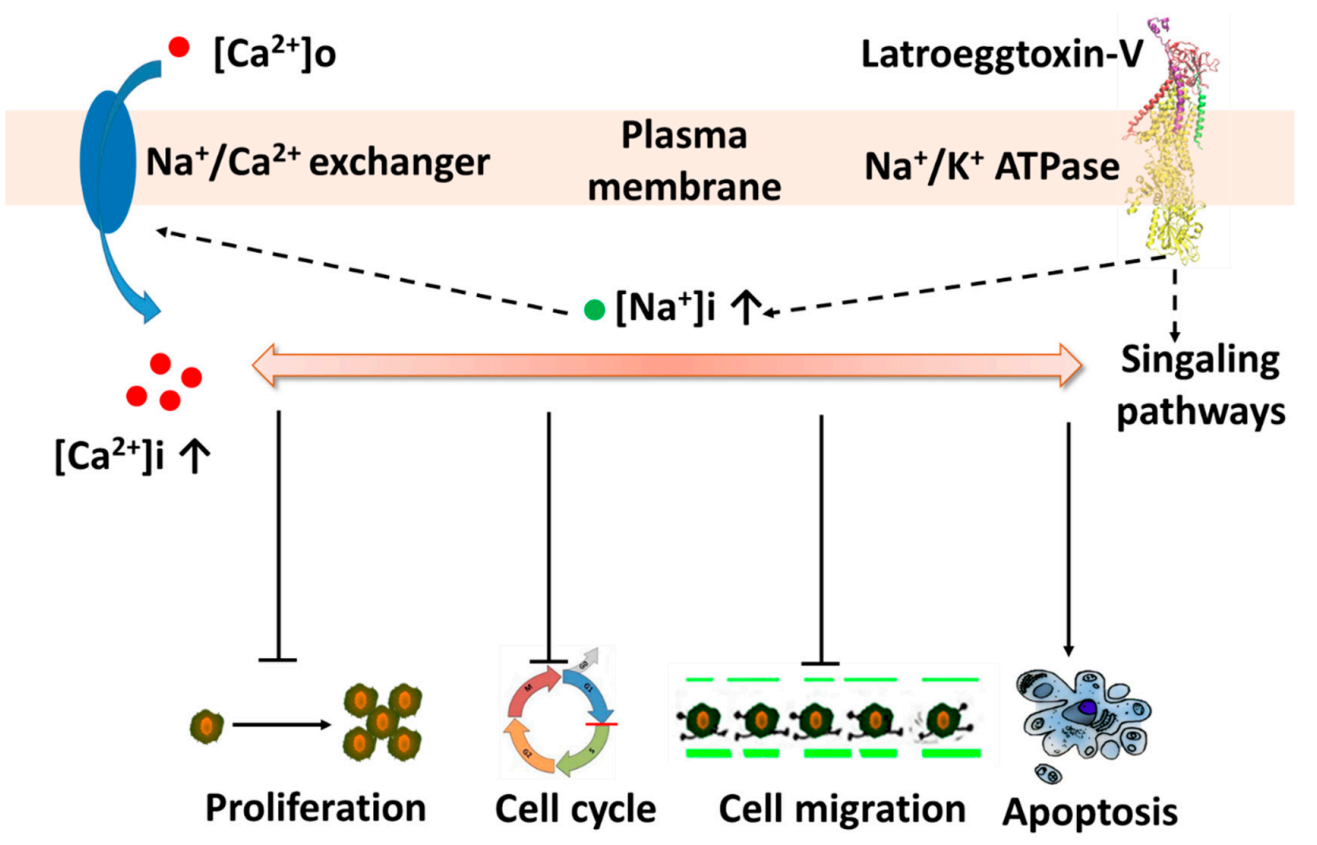

Figure 10. Diagram showing the putative actions of Latroeggtoxin-V on MDA-MB-231 cells through interaction with $\mathrm{Na}^{+} / \mathrm{K}^{+}$-ATPase.

\section{Conclusions}

The gene of Latroeggtoxin-V, a new proteinaceous toxin that was found for the first time by mining the transcriptome data of $L$. tredecimguttatus eggs with the help of bioinformatics, was successfully cloned and heterologously expressed in E. coli. The rLatroeggtoxin-V was demonstrated to be a $\mathrm{Na}^{+} / \mathrm{K}^{+}$-ATPase inhibitor and could selectively act on the breast cancer cell line MDA-MB-231 cells, arresting their cell cycle, inhibiting their proliferation and migration, and inducing their apoptosis. It was speculated that the adverse effects of Latroeggtoxin- $\mathrm{V}$ on the breast cancer cells were exerted via affecting both of the ion transport and the receptor functions of $\mathrm{Na}^{+} / \mathrm{K}^{+}$-ATPase in the cells. Due to the selective and multifaceted impacts of Latroeggtoxin- $\mathrm{V}$ on the cancer cells, this proteinaceous toxin displays a promising application foreground in the development of anti-breast cancer drugs and the related research. The present work has also provided a new transcriptomics and bioinformatics-directed paradigm for exploring the proteinaceous toxins with too low abundance to be isolated from the natural materials.

\section{Materials and Methods}

\subsection{Bioinformatic Analysis of Latroeggtoxin-V}

Some bioinformatics online software was used to analyze the Latroeggtoxin-V. The molecular weight (MW) and isoelectric point (pI) were analyzed by compute pI/MW tool of ExPASy (http://www.expasy.org/). The conserved domain and homologous sequence of Latroeggtoxin-V 
was searched by the CCD database (https://www.ncbi.nlm.nih.gov/cdd/) and BLASTP program (https:/ /blast.ncbi.nlm.nih.gov/Blast.cgi) in NCBI. PSIPRED (http:/ /bioinf.cs.ucl.ac.uk/psipred/) was used to analyze the secondary structure, and on this basis, the hydrophobic property and coiled-coil of $\alpha$-helix in Latroeggtoxin-V were analyzed by Heliquest (http:/ /heliquest.ipmc.cnrs.fr/) and COIL Server (https:/ / embnet.vital-it.ch/software/COILS_form.html).

\subsection{Gene Cloning of Latroeggtoxin- $V$}

Trizol reagent (Invitrogen ${ }^{\mathrm{TM}}$, Eugene, OR, USA) was used to extract the total RNA of the spider eggs 1-2 weeks before hatching. The purity, integrity and concentration of the extracted total RNA were detected by agarose gel electrophoresis and biophotometer (Eppendorf, Hamburg, Germany), respectively. According to the instructions in the manual of Superscript ${ }^{\mathrm{TM}} \mathrm{III}$ kit (Invitrogen ${ }^{\mathrm{TM}}$, Eugene, OR, USA), the total RNA was reversely transcripted to cDNA. Based on the Latroeggtoxin-V gene sequence obtained by the transcriptomic analysis of the eggs, a pair of gene-specific amplification primers were designed (Table 2). The prepared cDNA is used as the template for PCR amplification of Latroeggtoxin- $\mathrm{V}$ gene with the following program: initial denaturation $\left(94^{\circ} \mathrm{C}\right.$ for $\left.3 \mathrm{~min}\right), 30$ cycles including denaturation $\left(94^{\circ} \mathrm{C}\right.$ for $\left.30 \mathrm{~s}\right)$, annealing $\left(55^{\circ} \mathrm{C}\right.$ for $\left.30 \mathrm{~s}\right)$, elongation $\left(72{ }^{\circ} \mathrm{C}\right.$ for $\left.2 \mathrm{~min}\right)$, and final elongation $\left(72{ }^{\circ} \mathrm{C}\right.$ for $5 \mathrm{~min}$ ). The reaction system is $50 \mu \mathrm{L}$, including $3 \mu \mathrm{L}$ cDNA, $5 \mu \mathrm{L} 10 \times$ PCR buffer, $1 \mu \mathrm{L} 10 \mathrm{mM}$ dNTP Mix, $2 \mu \mathrm{L}$ F primer, $2 \mu \mathrm{L}$ R primer, $0.5 \mu \mathrm{L} p f u$ DNA polymerase (TIANGEN,

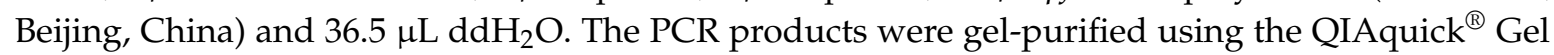
Extraction Kit (Qiagen, Duesseldorf, Germany) and ligated into the pMD19-T vector after being added with a poly (A) tail. The ligation products (named pMD19-T-Latroeggtoxin- $V$ ) were transformed into $\mathrm{DH} 5 \alpha$ competent cells, and the transformed cells were spread on a LB solid plate containing $100 \mu \mathrm{g} / \mathrm{mL}$ ampicillin. The next day, the colonies growing on the plate were picked for colony PCR detection. The positive colonies were sequenced by sequencing company to identify which contained the correct sequence.

Table 2. Primer sequences.

\begin{tabular}{cc}
\hline Primer Name & Primer Sequence $\left(5^{\prime} \rightarrow \mathbf{3}^{\prime}\right)$ \\
\hline Latroeggtoxin- $V-\mathrm{F}$ & CATGGGATCCGACGACGACGACAAGTCTCAGGCTGGTGAATGGGGTTCTG \\
Latroeggtoxin- $V$-R & CCG $\underline{\text { CTCGAGTTAACCGTCGATTTTTTTTTCTTCTTTAGC }}$ \\
\hline
\end{tabular}

Notes: The single underline indicates restriction endonuclease cleavage sites, whereas the double underline indicates enterokinase cleavage site. GGATCC and CTCGAG are cleavage sites of BamHI and XhoI, respectively.

\subsection{Prokaryotic Expression of Latroeggtoxin- $V$}

The pMD19-T-Latroeggtoxin- $V$ plasmids were extracted by a plasmid extraction kit (TIANGEN, Beijing, China) from correctly sequenced bacteria, and then the plasmids and pET-28a expression vectors were simultaneously digested with restriction endonuclease FastDigest BamHI and FastDigest XhoI (Thermo Fisher Scientific, Waltham, MA, USA). After gel-purification and ligation of the digested products with T4 ligase (Thermo Fisher Scientific, Waltham, MA, USA), the constructed recombinant vectors pET-28a-Latroeggtoxin- $V$ were transformed into BL21 (DE3). The transformed strains were plated on LB solid medium containing $100 \mu \mathrm{g} / \mathrm{mL}$ Kanamycin, and single colonies was selected for colony PCR detection after culturing at $37^{\circ} \mathrm{C}$ for $16 \mathrm{~h}$. The plasmids extracted from the colonies with positive colony PCR results were analyzed by double enzyme digestion and sequencing, and the strains with the correct analysis results were inoculated into the LB liquid medium containing $100 \mu \mathrm{g} / \mathrm{mL}$ Kanamycin and shaken at $37^{\circ} \mathrm{C}$ and $225 \mathrm{r} / \mathrm{min}$ overnight. The next day, the bacterial solution was inoculated into $50 \mathrm{~mL}$ of new LB liquid medium at a ratio of 1:50, which was shaken at $37^{\circ} \mathrm{C}$ and $225 \mathrm{r} / \mathrm{min}$ until the $\mathrm{OD}_{600}$ value reached 0.6-0.8. Prokaryotic expression was induced by the addition of IPTG (Isopropyl $\beta$-D-1-thiogalactopyranoside) to a final concentration of $0.25 \mathrm{mM}$. After $5 \mathrm{~h}$ of inducing incubation, SDS-PAGE was performed with a $12 \%$ SDS-polyacrylamide slab gel to detect the induced expression of Latroeggtoxin- $\mathrm{V}$ fusion protein. 


\subsection{Purification of Latroeggtoxin-V Fusion Protein}

After expanding culture and inducing expression, the bacterial culture was centrifuged at $6000 \mathrm{~g}$ for $5 \mathrm{~min}$ to collect the precipitate, which was then resuspended in a native lysis buffer $(50 \mathrm{mM}$ $\mathrm{NaH}_{2} \mathrm{PO}_{4}, 300 \mathrm{mM} \mathrm{NaCl}, 50 \mathrm{mM}$ imidazole, $\mathrm{pH}$.0). The bacterial suspension was treated with the Ultrasonic crusher JY99-IIDN (SCIENTZ, Ningbo, China), and then centrifuged at 10,000 $\mathrm{g}$ for $30 \mathrm{~min}$ to collect the supernatant. For purifying Latroeggtoxin- $\mathrm{V}$ fusion protein, the supernatant was made to pass through a nickel-NTA agarose column (Sangon Biotech, Shanghai, China) pre-equilibrated with the native lysis buffer. The non-target proteins binding to the nickel-NTA agarose column were washed sequentially using $20 \mathrm{~mL}$ native lysis buffer and washing buffer $\left(50 \mathrm{mM} \mathrm{NaH}_{2} \mathrm{PO}_{4}, 300 \mathrm{mM} \mathrm{NaCl}\right.$, $100 \mathrm{mM}$ imidazole, $\mathrm{pH} 8.0$ ). Latroeggtoxin-V fusion protein with His-tag was eluted with $40 \mathrm{~mL}$ elution buffer ( $50 \mathrm{mM} \mathrm{NaH}_{2} \mathrm{PO}_{4}, 300 \mathrm{mM} \mathrm{NaCl}, 250 \mathrm{mM}$ imidazole, $\mathrm{pH} 8.0$ ), followed by desalination and concentration with an ultrafiltration tube Millipore UFC901096 (Millipore UFC901096, Billerica, MA, USA). SDS-PAGE was used to detect the purity of the prepared Latroeggtoxin-V fusion protein sample.

\subsection{Cleavage of Latroeggtoxin-V Fusion Protein and Isolation of $r$ Latroeggtoxin-V}

The Latroeggtoxin- $\mathrm{V}$ fusion protein was cleaved by enterokinase at $25^{\circ} \mathrm{C}$ overnight in a cleavage buffer (20 mM Tris-HCl, $50 \mathrm{mM} \mathrm{NaCl}, 2 \mathrm{mM} \mathrm{CaCl}$, pH8.0) at an enzyme: substrate ratio of 1:50 (Sangon Biotech, Shanghai, China). The cleaved products were separated with RP-HPLC (SHIMADZU, Kyoto, Japan) using a C18 column $\left(4.6 \mathrm{~mm} \times 250 \mathrm{~mm}, 5 \mu \mathrm{m}\right.$ particle size, Welch Xtimate ${ }^{\mathrm{TM}}$, Shanghai, China). The cleaved products were eluted with a linear gradient of acetonitrile containing $0.1 \%$ TFA from $0 \%$ to $70 \%$ in $40 \mathrm{~min}$ at a flow rate of $1.0 \mathrm{~mL} / \mathrm{min}$. The molecular weight of the components in each elution peak was determined by electrospray ionization mass spectrometry (Waters ACQUITY UPLC/Xevo G2 QTOF, Waters, Milford, MA, USA) and thus the peak containing recombinant Latroeggtoxin-V (rLatroeggtoxin-V) was selected and lyophilized.

\subsection{Bioactivity Assessment of rLatroeggtoxin-V against MDA-MB-231 Cells}

\subsubsection{Cell Viability-Inhibiting Activity}

Human embryonic kidney 293 (HEK293) cells, non-tumor-derived cells used as control, and breast cancer cell line MDA-MB-231 cells (Shanghai cell bank of the Chinese Academy of Sciences, Shanghai, China) were cultured in DMEM/high glucose medium (Gibco ${ }^{\mathrm{TM}}$, Carlsbad, MA, USA) containing $10 \%$ fetal bovine serum (SERANA, Brandenburg, Germany) at $37^{\circ} \mathrm{C}, 5 \% \mathrm{CO}_{2}$ and a relative humidity of $90 \%$, using a carbon dioxide incubator (Thermo Fisher Scientific, Waltham, MA, USA). When the cells were cultured to exponential phase, they were dissociated with trypsin digestion (Hyclone $^{\mathrm{TM}}$, Logan, UT, USA), collected and then seeded in a 96 well plate at a concentration of $10^{3}$ cells / well. After incubation for $24 \mathrm{~h}$, the medium was removed by aspiration and replaced with $100 \mu \mathrm{L}$ of experimental medium containing 5 different concentrations of rLatroeggtoxin-V $(0,20,40,60$ and $80 \mu \mathrm{M}$ ), each of which was plated into 4 wells. After the toxin treatment was performed for $48 \mathrm{~h}$, the cell viability was assessed using the 3-(4,5-dimethylthiazol-2-yl)-2,5-diphenyltetrazolium bromide (MTT) assay (Byotime, Jiangsu, China). Ten $\mu \mathrm{L}$ of MTT reagent was added to each well and the plates were incubated in the dark for $4 \mathrm{~h}$ at $37^{\circ} \mathrm{C}$. Subsequently, the absorbance of MTT was measured at $490 \mathrm{~nm}$ by a Varioska Flash plate reader (Thermo Fisher Scientific, Waltham, MA, USA). The relative cell viability was calculated using the following equation: $A_{\text {test }} / A_{\text {control }} \times 100 \%$, where ' $A_{\text {control }}$ ' is the absorbance of the control ( $0 \mu \mathrm{M}$ rLatroeggtoxin- $V$ treatment $)$ and ' $A_{\text {test' }}$ ' is the absorbance of the tests.

\subsubsection{Apoptosis-Inducing Activity}

Hoechst 33258 staining strategy was used to observe the apoptotic morphology of the cells treated with rLatroeggtoxin-V. MDA-MB-231 cells were seeded in the 6 well plate ( $10^{6}$ cells/well), and divided into two groups: Control groups $(0 \mu \mathrm{M}$ rLatroeggtoxin-V treatment) and test groups of $(40 \mu \mathrm{M}$ rLatroeggtoxin-V treatment). After treatment for $48 \mathrm{~h}$, the cells were fixed with $4 \%$ formaldehyde for 
$10 \mathrm{~min}$ and washed in PBS twice. The cells were then stained with $0.5 \mathrm{~mL}$ of Hoechst 33258 (Beyotime, Jiangsu, China) for 5 min, washed in PBS twice, and photographed with an Olympus IX83 fluorescence microscopy (Olympus, Tokyo, Japan) at $360 \mathrm{~nm}$.

\subsubsection{Cell Migration-Inhibiting Activity}

Wound-healing assay was used to assess the effect of rLatroeggtoxin-V on MDA-MB-231 cell migration in culture. A 24 -well plate was seeded at $10^{5}$ cells/well and incubated until 100\% confluence was reached. The layer of cells was scratched with a $100-\mu \mathrm{L}$ pipette tip and washed with PBS three times to remove the detached cells. The incubation was continued for $24 \mathrm{~h}$ in fresh serum-free DMEM medium containing 4 different concentrations of rLatroeggtoxin- $\mathrm{V}(0,20,40$ and $80 \mu \mathrm{M})$, each of which was plated into 3 wells. The wound widths at 0 and $24 \mathrm{~h}$ after scratching were measured and photographed, respectively, with a DMLB2 microscopy (LEICA, Solms, Germany) to determine the effect of rLatroeggtoxin-V on the cell migration.

\subsubsection{Cell Cycle Arrest Activity}

The effect of rLatroeggtoxin-V on the cell cycle of MDA-MB-231 cells was assayed according to the method of Sun et al. [49]. Briefly, MDA-MB-231 cells were inoculated in 6 well plates at a concentration of $10^{6}$ cells / mL. After adhering to the wall, the cells were cultured in serum-free medium for $12 \mathrm{~h}$ so that they could grow synchronously. Different concentrations of rLatroeggtoxin-V $(0,25,50$ and $100 \mu \mathrm{M}$ ) were used to treat the cells for $48 \mathrm{~h}$, and then the cells were harvested, washed in cold PBS and fixed in $75 \%$ alcohol at $4{ }^{\circ} \mathrm{C}$ for $12 \mathrm{~h}$. The fixed cells were resuspended in PBS containing $0.25 \mathrm{mg} / \mathrm{mL}$ RNase A and $0.05 \mathrm{mg} / \mathrm{mL}$ propidium iodide (PI) for $30 \mathrm{~min}$, and analyzed using flow cytometry (Cytoflex, Beckman, Indianapolis, IN, USA).

\subsection{5. $\mathrm{Na}^{+} / \mathrm{K}^{+}$-ATPase-Inhibiting Activity}

The activity of the $\mathrm{Na}^{+} / \mathrm{K}^{+}$-ATPase in MDA-MB-231 cells was assayed as described [50-52]. MDA-MB-231 cells were seeded in 6-well plates at a density of $10^{6}$ cells/well in $1.8 \mathrm{~mL}$ volume and cultured overnight. Next day, the medium was removed by aspiration and replaced with $1.8 \mathrm{~mL}$ experimental medium containing 4 different concentrations of rLatroeggtoxin-V $(0,10,100$ and $1000 \mu \mathrm{M})$, each of which was plated into 3 wells. After treatment for $12 \mathrm{~h}$, the cells were harvested by trypsinization with $0.05 \%$ trypsin and suspended in a PBS buffer. The cells were disrupted by ultrasound (Power 20\%, time $3 \mathrm{~s}$, interval $10 \mathrm{~s}$, repeat 30 times), and the supernatant containing $\mathrm{Na}^{+} / \mathrm{K}^{+}$-ATPase was collected by $8000 \mathrm{~g}$ centrifugation at $4{ }^{\circ} \mathrm{C}$ for $10 \mathrm{~min}$. The $\mathrm{Na}^{+} / \mathrm{K}^{+}$-ATPase activity was evaluated with a $\mathrm{Na}^{+}-\mathrm{K}^{+}$-ATPase detection kit (Solarbio, Shanghai, China) according to the instructions of the manufacturer. The concentration of inorganic orthophosphate $\left(\mathrm{P}_{\mathrm{i}}\right)$ liberated from the hydrolysis of ATP was spectrophotometrically measured at $660 \mathrm{~nm}$. The amount of $\mathrm{Na}^{+} / \mathrm{K}^{+}-\mathrm{ATPase}$ decomposing ATP to produce 1 micromole $\mathrm{P}_{\mathrm{i}}$ per milligram of cell protein per hour is one enzyme activity unit. The protein concentration was determined by the BCA (bicinchoninic acid assay) method (Beyotime, Jiangsu, China) with human serum albumin as a standard.

\subsection{Statistical Analysis}

Data were expressed as mean \pm SD. Experimental data were analyzed using SPSS v19.0 statistical software (IBM Corp., Armonk, NY, USA, 2012) with the least significant differences between samples being $p<0.05$.

Author Contributions: The study was conceived by X.W.; D.X. performed the experiments and contributed to data collection and bioinformatics analysis; X.T., X.W., D.Y. and P.T. participated in partial experiments; X.W. and D.X. wrote the manuscript. All authors had read and approved the final manuscript.

Funding: This research and APC were funded by the National Natural Science Foundation of China [31870770, $31271135,31070700]$ and the crosswise project [53122-1371]. 
Conflicts of Interest: The authors declare no conflict of interest.

\section{References}

1. World Spider Catalog. World Spider Catalog Version 19.5. Natural History Museum Bern, 2018. Available online: http:/ / wsc.nmbe.ch/ (accessed on 14 August 2018).

2. Zhu, M.S. The Spiders of China Arachnida Araneae Theridiidae; Science Press: Beijing, China, 1998; pp. $293-294$. ISBN 9787030062437. (In Chinese)

3. Camp, N.E. Black widow spider envenomation. J. Emerg. Nurs. 2014, 40, 193-194. [CrossRef] [PubMed]

4. Hoxha, R. Two Albanians die from black widow spider bites. BMJ 2006, 333, 278. [CrossRef] [PubMed]

5. Yan, S.; Wang, X.C. Recent Advances in Research on Widow Spider Venoms and Toxins. Toxins 2015, 7, 5055-5067. [CrossRef] [PubMed]

6. He, Q.Z.; Duan, Z.G.; Yu, Y.; Liu, Z.; Liu, Z.H.; Liang, S.P. The venom gland transcriptome of Latrodectus tredecimguttatus revealed by deep sequencing and cDNA library analysis. PLoS ONE 2013, 8, e81357. [CrossRef] [PubMed]

7. Wang, X.C.; Duan, Z.G.; Yang, J.; Yan, X.J.; Zhou, H.; He, X.Z.; Liang, S.P. Physiological and biochemical analysis of L. tredecimguttatus venom collected by electrical stimulation. J. Physiol. Biochem. 2007, 63, 221-230. [CrossRef] [PubMed]

8. Duan, Z.G.; Yan, X.J.; He, X.Z.; Zhou, H.; Chen, P.; Cao, R.; Xiong, J.X.; Hu, W.J.; Wang, X.C.; Liang, S.P. Extraction and protein component analysis of venom from the dissected venom glands of Latrodectus tredecimguttatus. Comp. Biochem. Physiol. B Biochem. Mol. Biol. 2006, 145, 350-357. [CrossRef] [PubMed]

9. Duan, Z.G.; Yang, J.; Yan, X.J.; Zeng, X.Z.; Wang, X.C.; Liang, S.P. Venom properties of the spider Latrodectus tredecimguttatus and comparison of two venom-collecting methods. Zool. Res. 2009, 30, 381-388. [CrossRef]

10. Buffkin, D.C.; Russell, F.E.; Deshmukh, A. Preliminary study on the toxicity of black widow spider eggs. Toxicon 1971, 9, 393-402. [CrossRef]

11. Russell, F.E.; Maretć, Z. Effects of Latrodectus egg poison on web building. Toxicon 1979, 17, 649-650. [CrossRef]

12. Yan, Y.Z.; Li, J.J.; Zhang, Y.Y.; Peng, X.Z.; Guo, T.Y.; Wang, J.R.; Hu, W.J.; Duan, Z.G.; Wang, X.C. Physiological and biochemical characterization of egg extract of black widow spiders to uncover molecular basis of egg toxicity. Biol. Res. 2014, 47, 1-11. [CrossRef] [PubMed]

13. Li, J.J.; Liu, H.; Duan, Z.G.; Cao, R.; Wang, X.C.; Liang, S.P. Protein compositional analysis of the eggs of black widow spider (Latrodectus tredecimguttatus): Implications for the understanding of egg toxicity. J. Biochem. Mol. Toxicol. 2012, 26, 510-515. [CrossRef] [PubMed]

14. Li, J.J.; Yan, Y.Z.; Wang, J.R.; Guo, T.Y.; Hu, W.J.; Duan, Z.G.; Wang, X.C.; Liang, S.P. Purification and partial characterization of a novel neurotoxic protein from eggs of black widow spiders (Latrodectus tredecimguttatus). J. Biochem. Mol. Toxicol. 2013, 27, 337-342. [CrossRef] [PubMed]

15. Li, J.J.; Yan, Y.Z.; Yu, H.; Peng, X.Z.; Zhang, Y.Y.; Hu, W.J.; Duan, Z.G.; Wang, X.C.; Liang, S.P. Isolation and identification of a sodium channel-inhibiting protein from eggs of black widow spiders. Int. J. Biol. Macromol. 2014, 65, 115-120. [CrossRef] [PubMed]

16. Lei, Q.; Yu, H.; Peng, X.Z.; Yan, S.; Wang, J.R.; Yan, Y.Z.; Wang, X.C. Isolation and preliminary characterization of proteinaceous toxins with insecticidal and antibacterial activities from black widow spider (L. tredecimguttatus) eggs. Toxins 2015, 7, 886-899. [CrossRef] [PubMed]

17. Nagalakshmi, U.; Waern, K.; Snyder, M. RNA-Seq: A Method for Comprehensive Transcriptome Analysis. Curr. Protoc. Mol. Biol. 2010, 89, 1-13. [CrossRef]

18. Hoeijmakers, W.A.; Bártfai, R.; Stunnenberg, H.G. Transcriptome analysis using RNA-Seq. Met. Mol. Biol. 2013, 923, 221-239. [CrossRef]

19. Xu, D.H.; Wang, X.C. Transcriptome Analysis to Understand the Toxicity of Latrodectus tredecimguttatus Eggs. Toxins 2016, 8, 378. [CrossRef] [PubMed]

20. Lu, J.; Chen, Z.W. Isolation, characterization and anti-cancer activity of SK84, a novel glycine-rich antimicrobial peptide from Drosophila virilis. Peptides 2010, 31, 44-50. [CrossRef] [PubMed]

21. Lu, J.; Chen, Z.W.; Wu, Y.; Ding, J.P.; Cederlund, E.; Jörnvall, H.; Bergman, T. An ATPase inhibitory peptide with antibacterial and ion current effects. Biochem. Biophys. Res. Commun. 2014, 446, 519-522. [CrossRef] [PubMed] 
22. Rose, A.; Meier, I. Scaffolds, levers, rods and springs: Diverse cellular functions of long coiled-coil proteins. Cell. Mol. Life Sci. 2004, 61, 1996-2009. [CrossRef] [PubMed]

23. Geering, K. Na, K-ATPase. Curr. Opin. Nephrol. Hypertens. 1997, 6, 434-439. [CrossRef] [PubMed]

24. Aperia, A. New roles for an old enzyme: Na, K-ATPase emerges as an interesting drug target. J. Intern. Med. 2007, 261, 44-52. [CrossRef] [PubMed]

25. $\mathrm{Yu}$, S.P. $\mathrm{Na}^{+}, \mathrm{K}^{+}$-ATPase: The new face of an old player in pathogenesis and apoptotic/hybrid cell death. Biochem. Pharmacol. 2003, 66, 1601-1609. [CrossRef]

26. Xiao, A.Y.; Wei, L.; Xia, S.; Rothman, S.; Yu, S.P. Ionic mechanism of ouabain-induced concurrent apoptosis and necrosis in individual cultured cortical neurons. J. Neurosci. 2002, 22, 1350-1362. [CrossRef] [PubMed]

27. Archibald, J.T.; White, T.D. Rapid reversal of internal $\mathrm{Na}^{+}$and $\mathrm{K}^{+}$contents of synaptosomes by ouabain. Nature 1974, 252, 595-606. [CrossRef] [PubMed]

28. Berridge, M.J.; Bootman, M.D.; Roderick, H.L. Calcium signalling: Dynamics, homeostasis and remodelling. Nat. Rev. Mol. Cell Biol. 2003, 4, 517-529. [CrossRef] [PubMed]

29. Aperia, A.; Akkuratov, E.E.; Fontana, J.M.; Brismar, H. Na-K-ATPase, a new class of plasma membrane receptors. Am. J. Physiol. Cell Physiol. 2016, 310, 491-495. [CrossRef] [PubMed]

30. Pierre, S.V.; Xie, Z. The Na, K-ATPase receptor complex: Its organization and membership. Cell Biochem. Biophys. 2006, 46, 303-316. [CrossRef]

31. Chen, J.Q.; Contreras, R.G.; Wang, R.; Fernandez, S.V.; Shoshani, L.; Russo, I.H.; Cereijido, M.; Russo, J. Sodium/potassium ATPase $\left(\mathrm{Na}^{+}, \mathrm{K}^{+}\right.$-ATPase) and ouabain/related cardiac glycosides: A new paradigm for development of anti- breast cancer drugs? Breast Cancer Res. Treat. 2006, 96, 1-15. [CrossRef] [PubMed]

32. Felippe Gonçalves-de-Albuquerque, C.; Ribeiro Silva, A.; Ignácio da Silva, C.; Caire Castro-Faria-Neto, H.; Burth, P. Na/K pump and beyond: Na/K-ATPase as a modulator of apoptosis and autophagy. Molecules 2017, 22, 578. [CrossRef] [PubMed]

33. Alevizopoulos, K.; Calogeropoulou, T.; Lang, F.; Stournaras, C. $\mathrm{Na}^{+} / \mathrm{K}^{+}$ATPase inhibitors in cancer. Curr. Drug Targets 2014, 15, 988-1000. [CrossRef] [PubMed]

34. Mijatovic, T.; Dufrasne, F.; Kiss, R. Na $/ \mathrm{K}^{+}$-ATPase and cancer. Pharm Pat. Anal. 2012, 1, 91-106. [CrossRef] [PubMed]

35. Magpusao, A.N.; Omolloh, G.; Johnson, J.; Gascón, J.; Peczuh, M.W.; Fenteany, G. Cardiac glycoside activities link $\mathrm{Na}^{+} / \mathrm{K}^{+}$ATPase ion-transport to breast cancer cell migration via correlative SAR. ACS Chem. Biol. 2015, 10, 561-569. [CrossRef] [PubMed]

36. Kometiani, P.; Liu, L.; Askari, A. Digitalis-induced signaling by $\mathrm{Na}^{+} / \mathrm{K}^{+}$-ATPase in human breast cancer cells. Mol. Pharmacol. 2005, 67, 929-936. [CrossRef] [PubMed]

37. Baskar, R.; Lee, K.A.; Yeo, R.; Yeoh, K.W. Cancer and radiation therapy: Current advances and future directions. Int. J. Med. Sci. 2012, 9, 193-199. [CrossRef] [PubMed]

38. Libério, M.S.; Joanitti, G.A.; Fontes, W.; Castro, M.S. Anticancer peptides and proteins: A panoramic view. Protein Pept. Lett. 2013, 20, 380-391. [CrossRef] [PubMed]

39. Zhang, C.; Xie, S.H.; Xu, B.; Lu, S.; Liu, P. Digitalis use and the risk of breast cancer: A systematic review and meta-analysis. Drug Saf. 2017, 40, 285-292. [CrossRef] [PubMed]

40. Ahern, T.P.; Tamimi, R.M.; Rosner, B.A.; Hankinson, S.E. Digoxin use and risk of invasive breast cancer: Evidence from the Nurses' Health Study and meta-analysis. Breast Cancer Res. Treat. 2014, 144, 427-435. [CrossRef] [PubMed]

41. Wu, D.; Gao, Y.; Qi, Y.; Chen, L.; Ma, Y.; Li, Y. Peptide-based cancer therapy: Opportunity and challenge. Cancer Lett. 2014, 351, 13-22. [CrossRef] [PubMed]

42. Zhang, Y. Why do we study animal toxins? Zool. Res. 2015, 36, 183-222. [CrossRef] [PubMed]

43. Jeong, Y.J.; Choi, Y.; Shin, J.M.; Cho, H.J.; Kang, J.H.; Park, K.K.; Choe, J.Y.; Bae, Y.S.; Han, S.M.; Kim, C.H.; et al. Melittin suppresses EGF-induced cell motility and invasion by inhibiting PI3K/Akt/mTOR signaling pathway in breast cancer cells. Food Chem. Toxicol. 2014, 68, 218-225. [CrossRef] [PubMed]

44. D'Suze, G.; Rosales, A.; Salazar, V.; Sevcik, C. Apoptogenic peptides from Tityus discrepans scorpion venom acting against the SKBR3 breast cancer cell line. Toxicon 2010, 56, 1497-1505. [CrossRef] [PubMed]

45. Conlon, J.M.; Prajeep, M.; Mechkarska, M.; Arafat, K.; Attoub, S.; Adem, A.; Pla, D.; Calvete, J.J. Peptides with in vitro anti-tumor activity from the venom of the Eastern green mamba, Dendroaspis angusticeps (Elapidae). J. Venom Res. 2014, 5, 16-21. [PubMed] 
46. Cabezón, E.; Runswick, M.J.; Leslie, A.G.; Walker, J.E. The structure of bovine IF1, the regulatory subunit of mitochondrial F-ATPase. EMBO J. 2001, 20, 6990-6996. [CrossRef] [PubMed]

47. Apostolovic, B.; Danial, M.; Klok, H.A. Coiled coils: Attractive protein folding motifs for the fabrication of self-assembled, responsive and bioactive materials. Chem. Soc. Rev. 2010, 39, 3541-3575. [CrossRef] [PubMed]

48. Wu, Y.; Collier, J.H. $\alpha$-Helical coiled-coil peptide materials for biomedical applications. Wiley Interdiscip. Rev. Nanomed. Nanobiotechnol. 2017, 9, e1424. [CrossRef] [PubMed]

49. Sun, M.N.; Zhao, X.J.; Zhao, H.D.; Zhang, W.G.; Li, F.L.; Chen, M.Z.; Li, H.; Li, G. Recombinant Escherichia coli Trx-JZTX-III represses the proliferation of mouse hepatocellular carcinoma cells through induction of cell cycle arrest. Mol. Med. Rep. 2013, 7, 1800-1804. [CrossRef] [PubMed]

50. El Moussawi, L.; Chakkour, M.; Kreydiyyeh, S.I. Epinephrine modulates $\mathrm{Na}^{+} / \mathrm{K}^{+}$ATPase activity in Caco-2 cells via Src, p38MAPK, ERK and PGE2. PLoS ONE 2018, 13, e0193139. [CrossRef] [PubMed]

51. El-Zein, O.; Usta, J.; El Moussawi, L.; Kreydiyyeh, S.I. Leptin inhibits the $\mathrm{Na}^{+} / \mathrm{K}^{+}$ATPase in Caco-2 cells via PKC and p38MAPK. Cell. Signal. 2015, 27, 416-423. [CrossRef] [PubMed]

52. Esmann, M. ATPase and phosphatase activity of $\mathrm{Na}^{+}, \mathrm{K}^{+}$-ATPase: Molar and specific activity, protein determination. Methods Enzymol. 1988, 156, 105-109. [PubMed]

(c) 2018 by the authors. Licensee MDPI, Basel, Switzerland. This article is an open access article distributed under the terms and conditions of the Creative Commons Attribution (CC BY) license (http://creativecommons.org/licenses/by/4.0/). 